\title{
Natural variations of citrate and calcium in milk and their effects on milk processing properties
}

\author{
M. Akkerman, ${ }^{1}$ L. B. Larsen, ${ }^{1}$ J. Sørensen, ${ }^{2}$ and N. A. Poulsen ${ }^{1 *}$ \\ ${ }^{1}$ Aarhus University, Department of Food Science, Foulum, 8830 Tjele, Denmark \\ ${ }^{2}$ Arla Foods Innovation Centre, Aarhus, 8200 Aarhus N, Denmark
}

\section{ABSTRACT}

Natural variations among milk constituents, and their relations to each other as well as to processing parameters, represent possibilities for differentiation of milk to produce high-quality natural products. In this study, we focused on natural variations in milk citrate and its interplay with calcium distribution in milk, in relation to processing properties. Milk samples from individual cows from farms varying in feeding and management practices were collected from April to June 2017 to maximize natural variations in citrate and calcium. Chemical composition, rennet coagulation properties, and ethanol stability were analyzed for all milk samples. We focused particularly on calcium distribution and citrate content and the correlation of these to other milk parameters. No significant change in citrate content was observed during the sampling period, which suggests that mechanisms other than feeding affect citrate levels in milk. Several significant correlations were found, including a positive correlation between complexed serum calcium and citrate, and a negative correlation between urea and ionic calcium. These are both of interest in relation to further processing, as with regard to the stability of UHT milk and in cheese making. Although the correlation between complexed serum calcium and citrate may be explained by their affinity, the underlying driver for the negative relationship between natural milk urea and ionic calcium needs to be clarified by further studies. Furthermore, milk from the different farms varied not only with regard to organic versus conventional farming systems; feeding practices between farms also play an important role in milk composition and functionality. However, none of the differences in milk composition between farms were

Received December 21, 2018.

Accepted April 2, 2019.

*Corresponding author: nina.poulsen@food.au.dk found to decrease milk functionality and thus would probably not cause any processing problems.

Key words: milk, citrate, calcium distribution, milk urea

\section{INTRODUCTION}

Calcium and citrate are important milk components. It is known that the content and distribution of these constituents play an essential role in milk quality and processing properties, such as rennet coagulation properties and UHT milk stability (Boumpa et al., 2008; Lewis et al., 2011; Nian et al., 2012). On average, total calcium content in bovine milk is $30 \mathrm{mM}$, of which approximately $66 \%$ is bound in the casein micelles. The remainder is found in serum, either as ionic calcium or as calcium bound in complexes, mainly with citrate (Gaucheron, 2005). Less than $10 \%$ of total calcium is found in the ionic form (Lewis, 2011). Total calcium, micellar calcium, and serum calcium are all positively correlated (Holt, 1982). However, the correlation between ionic calcium and the other calcium fractions is unclear (Gaucheron, 2005). Lin et al. (2006) found variations in ionic calcium between individual cows with equal levels of total calcium. The approximate level of citrate in milk is $10 \mathrm{mM}$, of which $89 \%$ is found as soluble citrate and the remainder is bound to casein micelles (Holt and Jenness, 1984). Soluble citrate can form complexes, mainly with calcium, which is one of the buffering salts in milk (Faulkner and Peaker, 1982).

Only a few studies have looked into the natural variations in and possible correlations between calcium and citrate contents and how such an association may affect processing properties. White and Davies (1958) reported a positive correlation between complexed serum calcium and soluble citrate in individual cow's milk. More recently, similar results were observed by analyzing bulk tank milk (Bijl et al., 2013).

Garnsworthy et al. (2006) observed higher citrate levels in early lactation compared with mid- and late lactation, which was found to be independent of milk yield or diet. Because citrate is a central component 
in the de novo synthesis of fatty acids in the mammary glands, factors affecting this synthesis may also affect milk citrate levels. Faulkner et al. (1986) found an increase in milk citrate during the grazing season. This could be related to a decrease in short-chain saturated de novo fatty acids (C4:0 to $\mathrm{C} 16: 0)$, which was observed by Elgersma et al. (2004) and Couvreur et al. (2006), when the amount of fresh grass in the feeding is increased.

Several laboratory studies have investigated the effect of manipulating the calcium balance of milk by addition of calcium or chelating agents, relating this to milk functionality. Manipulation of calcium equilibrium in milk by adding calcium in the form of calcium chloride results in increased levels of ionic calcium, which has been reported to decrease ethanol stability and stability of UHT milk by increasing the formation of sediment (Nian et al., 2012). In contrast, rennet coagulation properties are improved by faster rennet coagulation and formation of firmer gels, mainly caused by increases in ionic calcium levels (Tsioulpas et al., 2007a). With the addition of citrate, Boumpa et al. (2008) observed a reduction in ionic calcium content and an increase in ethanol stability after sterilization and UHT treatment of goat milk. Furthermore, higher natural citrate levels are found to reduce the rennetinduced coagulation properties of milk, through longer gelation time and production of less firm gels (Udabage et al., 2001; Sundekilde et al., 2014).

The natural variations in citrate and calcium fractions, their interrelations, and their possible effects on milk functionality have, however, not been thoroughly investigated. The aim of this study was to explore natural variations in calcium composition and distribution, along with citrate levels, and to relate these to functional properties of milk. This was done by studying individual milk samples from cows from 3 farms with different feeding practices (pasture vs. indoor feeding) and management systems (organic vs. conventional systems).

\section{MATERIALS AND METHODS}

\section{Dairy Farms and Feeding Strategies}

Three dairy farms were included in this study. Two of the farms were organic dairy herds (O1 and O2), with parlor milking systems and milking each morning and afternoon. Following organic farm regulations, these cows were put on pasture at least $6 \mathrm{~h}$ per day from April 15 to November 1, weather conditions and cow health permitting (European Council, 2007). The third farm was a conventional dairy herd $(\mathbf{C 1})$ with an automatic milking unit (AMU; DeLaval AB, Tumba, Sweden), with a minimum of $6 \mathrm{~h}$ between each milking. These cows did not go on pasture but were kept indoors all year. The farms were included on the basis of variations in milk composition, as the feed and management practices of the farms were different. Farm-specific feeding plans were provided by the dairy farmers, and relative feed proportions of grass silage, maize silage, grass, grain, concentrate, and whole crops were calculated. Feed proportions for the farms during indoor feeding periods and pasture feeding periods are summarized in Table 1. Cows on farm $\mathrm{C} 1$ did not go on summer pasture but had a minor change in feed composition between sampling periods (Table 1). Farm O2 used a limited amount of concentrate in their feeding system. Farm C1 had the largest amount of concentrate in its feeding system, and the organic farms fed more grains. Both organic farms used whole crops in their feeding systems. Farm O2 had a high degree of self-sufficient feed production, which is reflected in a relatively large whole-crop supplement, consisting mainly of fava beans and maize silage. Farms $\mathrm{C} 1$ and $\mathrm{O} 2$ had relatively high shares of maize silage, whereas $\mathrm{O} 1$ fed only grass silage. The feeding practices of the organic farms underwent large changes when the cows went on pasture: both farms decreased the amount of grains, whole crops, and silage in the feeding system. Farm $\mathrm{O} 1$ had a small increase in concentrate, but $\mathrm{O} 2$ had no change. In

Table 1. Gross composition of feed proportions at 3 farms $^{1}$ during indoor feeding and pasture feeding (organic farms only)

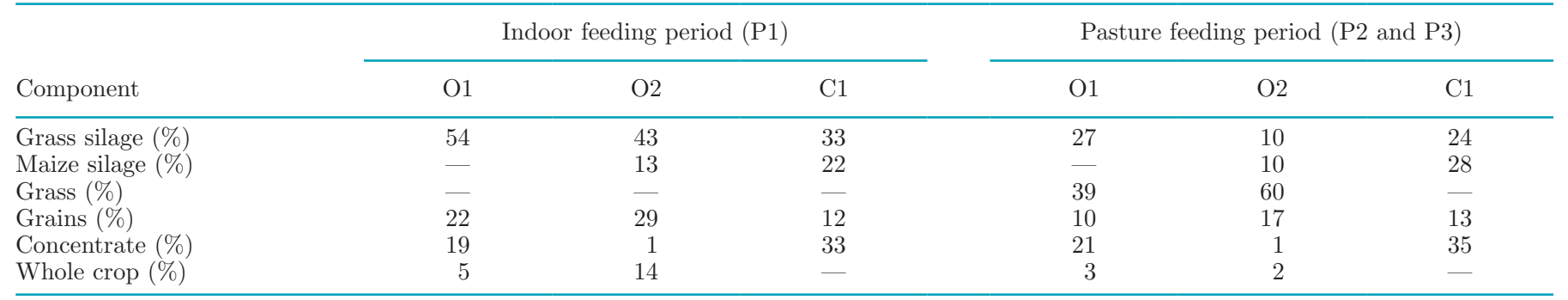

${ }^{1} \mathrm{O} 1, \mathrm{O} 2$ : organic farms; C1: conventional dairy farm. 
contrast, O2 had 20\% more fresh grass in the feeding system than did $\mathrm{O} 1$.

\section{Cow Selection and Milk Collection}

Individual cows from 3 different dairy farms were involved in this study. Cows included in the study were healthy Holsteins with no signs of clinical mastitis. Morning milk from the organic farms was collected on 3 separate days from April to June 2017, representing 3 feeding periods, $\mathbf{P 1}, \mathbf{P 2}$, and $\mathbf{P 3}$ : P1 reflects indoor feeding, P2 reflects pasture feeding after approximately two weeks for the organic farms only, and P3 reflects indoor feeding period 2 for $\mathrm{C} 1$ or pasture feeding for $\mathrm{O} 1$ and $\mathrm{O} 2$, approximately 6 weeks after P1. Milk was collected from the morning milking of 12 to 16 individual cows from each farm at each sampling date, $1 \mathrm{~L}$ of which was used for further analyses. If possible, the same cows were sampled at all sampling times. For the selected cows, DIM varied from 65 to 296 d, with an average DIM of 148.59 at P1, 174.11 at P2, and 205.57 d at P3.

Milk samples were transported in cooling boxes to the laboratory within a few hours of milking, and samples were analyzed or frozen on the same day. In total, 129 individual milk samples were collected, with 94 samples from organic cows: 36 at P1, 29 at P2, and 29 at P3. From the conventional cows, 19 individual samples were collected at P1 and 16 at P3.

\section{Compositional Analyses of Milk}

Fresh, full-fat milk was analyzed for protein, lactose, fat, urea, and citrate content via infrared spectroscopy (Milkoscan FT2, Foss Analytical, Hillerød, Denmark). The instrument was routinely calibrated according to these milk parameters by use of calibration samples provided by Eurofins Scientific (Vejen, Denmark). All milk samples were skimmed by centrifugation at 2,600 $\times g$ for $30 \mathrm{~min}$ at $4^{\circ} \mathrm{C}$ and afterward stored at $4^{\circ} \mathrm{C}$ until analysis or frozen for later analysis. We determined pH using a PHM220 pH meter (Radiometer Analytical, Copenhagen, Denmark), and conductivity was determined using a CDM210 conductivity meter (Radiometer Analytical) in fresh skim milk stored at room temperature for $2 \mathrm{~h}$ before measurement. For analysis of serum calcium, fresh skim milk samples were ultracentrifuged at $100,000 \times g$ for $1 \mathrm{~h}$ at $21^{\circ} \mathrm{C}$ (OptimaTM L-80 XP Ultracentrifuge, Beckman Coulter, Brea, CA), and the skim milk serum was collected and stored at $-20^{\circ} \mathrm{C}$ until time of analysis. For total calcium analysis, $15 \mathrm{~mL}$ of skim milk was frozen at $-20^{\circ} \mathrm{C}$ until time of analysis. Total calcium and serum calcium were determined by potentiometric titration
(862 compact titrosampler, Metrohm AG, Herisau, Switzerland) as described by Poulsen et al. (2017a), with a few modifications. In brief, 2 to $3 \mathrm{~g}$ of defrosted skim milk or skim milk serum were transferred to titration tubes. Ten milliliters of $0.1 M$ borax buffer and 60 $\mathrm{mL}$ of demineralized water were added. Potentiometric titration was performed using $0.01 M$ EGTA in a 0.1 $M \mathrm{KOH}$ solution against a calcium-selective electrode ( $\mathrm{scION}$, Metrohm AG) along with a double-junction $\mathrm{Ag} / \mathrm{AgCl}$ reference electrode (LL ISE, Metrohm AG). Calibration was performed using a $0.1 \mathrm{M} \mathrm{CaCl}_{2}$ solution. Micellar calcium was calculated by subtracting serum calcium from the total calcium concentration. Ionic calcium was measured in fresh skim milk samples, which had been at room temperature for approximately 30 min before analysis, using a portable calcium ionselective electrode (LAQUAtwin $\mathrm{Ca}^{2+}$ meter, Horiba Scientific, Kyoto, Japan), as described by Poulsen et al. (2017b). Calibration was performed using $\mathrm{CaCl}_{2}$ standard solutions of $0.5,1.0,2.5$, and $5.0 \mathrm{mM} \mathrm{CaCl}_{2}$ prepared with a $67.5 \mathrm{mM} \mathrm{KCl}, 13.5 \mathrm{~m} M$ imidazole solution. Ionic calcium concentration was estimated by Nernst equation. All measurements were performed in triplicate. Complexed serum calcium was calculated by subtracting ionic calcium from serum calcium concentrations. Calcium content and distribution were determined as total, serum, complexed serum, micellar, and ionic calcium.

\section{Analyses of Milk Physical Properties}

The coagulation properties of fresh skim milk were calculated using a ReoRox G2 rheometer (Medirox AB, Tystberga, Sweden). The method used was essentially as described by Frederiksen et al. (2011). Skim milk samples were incubated in a water bath at $33^{\circ} \mathrm{C}$ for 30 min. Chy-Max Extra chymosin (Chr. Hansen, Hørsholm, Denmark) was added to $10 \mathrm{~mL}$ of milk to achieve a final rennet concentration of 0.04 international milk clotting units (IMCU) per $\mathrm{mL}$ of milk. The addition of chymosin defined the starting point for the analysis. Rheological measurements were performed for $1 \mathrm{~h}$ at $33^{\circ} \mathrm{C}$. Coagulation analysis was performed in duplicate for all milk samples. Rennet coagulation time (RCT) is defined as the time during which the phase angle of the gelation process is $45^{\circ}$. Curd firming rate (CFR) is calculated from the linear part of the gelation profile and recorded in $\mathrm{Pa} / \mathrm{min}$, as defined by Frederiksen et al. (2011).

Ethanol stability was defined as the highest concentration of ethanol solution added to milk not causing any visual coagulation. Ethanol concentrations from 40 to $100 \%$ ethanol, with 2-percentage-unit increments in concentration, were mixed with equal amounts of milk 
and incubated at room temperature for $30 \mathrm{~min}$ before being checked for visible coagulation (Tsioulpas et al., 2007b).

\section{Statistical Analysis}

Statistical analysis was performed using $\mathrm{R}$ (version 3.0.3; R Foundation for Statistical Computing, Vienna, Austria). A 2-way ANOVA test was performed to test differences between farms (O1, O2, and $\mathrm{C} 1)$ and feeding periods (P1, P2, and P3). Pairwise comparisons were analyzed using Tukey's post hoc test. A Pearson's correlation test was used to determine the linear relationships between the 2 variables. Differences were deemed statistically significant when $P \leq 0.05$.

\section{RESULTS}

The results presented in this study explore how specific milk components related to calcium and citrate in milk are interrelated and further document natural differences in milk composition and functional properties, such as rennet coagulation and ethanol stability, among 3 farms. The farms were selected based on differences in management and feeding, to achieve a large natural variation in milk composition across commonly used dairy production systems in Denmark. Changes in milk composition and functional properties were also explored as effects of pasture feeding in organic production.

\section{Correlation Between Milk Variables}

Milk composition and functionality traits across farms and feeding periods were used to test for significant correlations between traits. Analysis revealed 26 significant correlations. Correlation coefficients and $P$-values of these correlations are shown in Table 2 . We found 21 correlations to be moderately strong, with correlation coefficients from 0.5 to 0.8 . The correlation between complexed serum calcium and serum calcium was strong, with a correlation coefficient of 0.98. Citrate was positively correlated with total, serum, and complexed serum calcium, with correlation coefficients of $0.60,0.67$, and 0.68 , respectively. Total calcium was positively correlated with both serum $(\mathrm{r}=0.75)$ and micellar calcium $(\mathrm{r}=0.49)$. The positive relationship between citrate and complexed serum calcium $(\mathrm{r}=0.68)$ is shown in Figure 1A. Ionic calcium was correlated with serum calcium, ethanol stability, and urea, with correlation coefficients of $0.64,-0.69$, and -0.65 , respectively. The negative relationship between

\begin{tabular}{|c|c|c|c|}
\hline Composition trait & Correlated trait & $\mathrm{r}$ & $P$-value \\
\hline \multirow[t]{3}{*}{ Protein vs. } & Micellar calcium & 0.50 & 0.039 \\
\hline & $\mathrm{pH}$ & -0.53 & 0.028 \\
\hline & $\mathrm{CFR}^{1}$ & 0.61 & 0.001 \\
\hline \multirow[t]{3}{*}{ Citrate vs. } & Total calcium & 0.60 & 0.011 \\
\hline & Serum calcium & 0.67 & 0.003 \\
\hline & Complexed calcium & 0.68 & 0.000 \\
\hline \multirow{2}{*}{ Total calcium vs. } & Micellar calcium & 0.75 & 0.001 \\
\hline & Serum calcium & 0.49 & 0.044 \\
\hline \multirow[t]{3}{*}{ Complexed serum calcium vs. } & Lactose & -0.44 & 0.032 \\
\hline & Serum calcium & 0.98 & 0.000 \\
\hline & Micellar calcium & -0.53 & 0.008 \\
\hline \multirow[t]{5}{*}{ Ionic calcium vs. } & Serum calcium & 0.64 & 0.006 \\
\hline & Ethanol stability & -0.69 & 0.002 \\
\hline & $\mathrm{RCT}^{2}$ & -0.58 & 0.003 \\
\hline & Urea & -0.65 & 0.005 \\
\hline & Lactose & -0.48 & 0.049 \\
\hline \multirow[t]{2}{*}{ Milk pH vs. } & $\mathrm{RCT}$ & 0.54 & 0.006 \\
\hline & CFR & -0.58 & 0.003 \\
\hline \multirow[t]{2}{*}{ Conductivity vs. } & Fat & 0.55 & 0.024 \\
\hline & Lactose & -0.74 & 0.001 \\
\hline \multirow[t]{4}{*}{ Ethanol stability vs. } & $\mathrm{RCT}$ & 0.61 & 0.018 \\
\hline & Fat & -0.56 & 0.020 \\
\hline & Lactose & 0.66 & 0.004 \\
\hline & Conductivity & -0.57 & 0.018 \\
\hline \multirow[t]{2}{*}{ RCT vs. } & CFR & -0.57 & 0.003 \\
\hline & Serum calcium & -0.52 & 0.007 \\
\hline
\end{tabular}

${ }^{1}$ CFR: curd firming rate.

${ }^{2} \mathrm{RCT}$ : rennet coagulation time. 

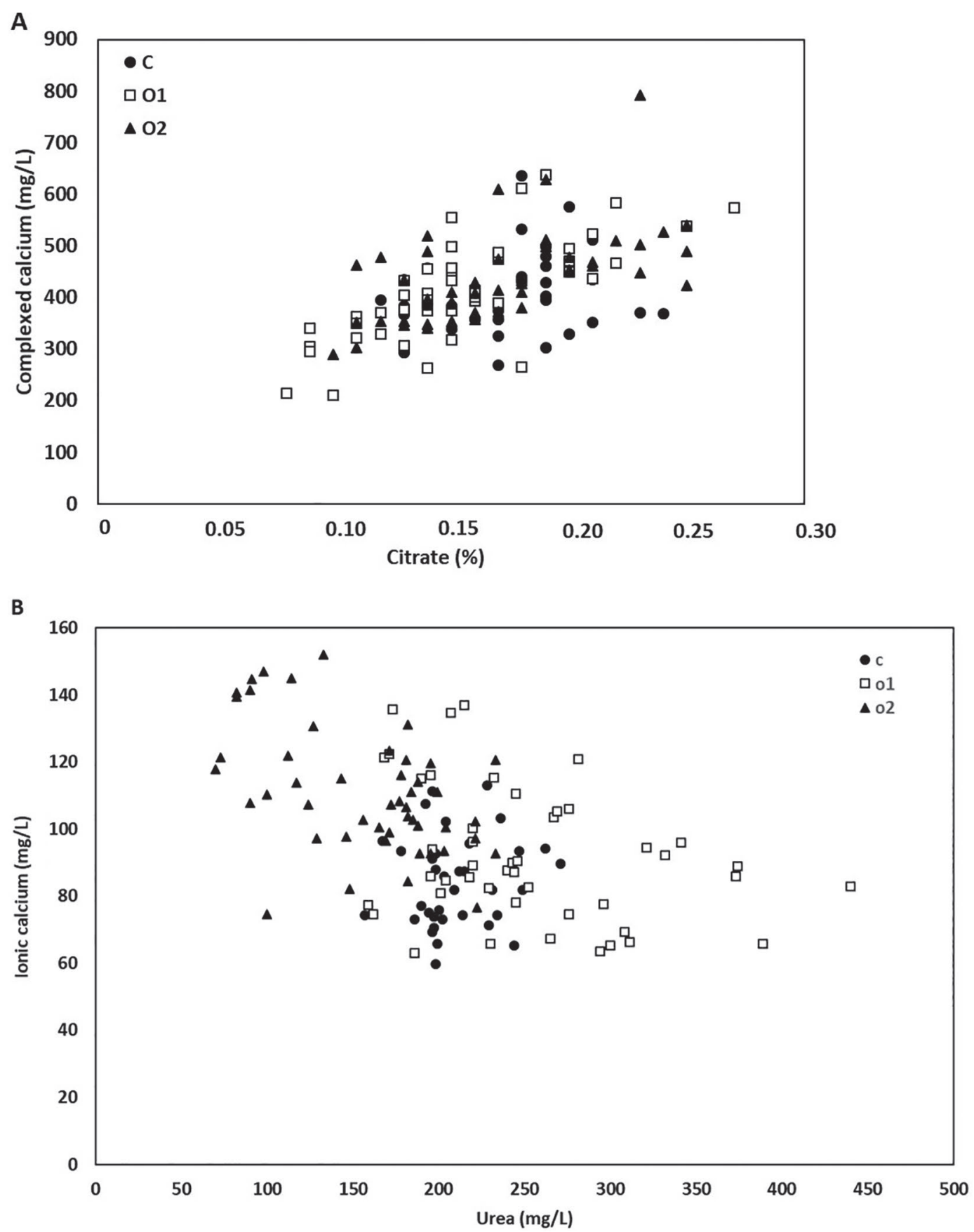

Figure 1. (A) Relationship between citrate (\%) and complexed serum calcium (mg/L). (B) Relationship between urea (mg/L) and ionic calcium $(\mathrm{mg} / \mathrm{L})$. Samples are marked according to farm: $\mathrm{C} 1=$ conventional dairy farm; O1, O2 = organic farms.

ionic calcium and urea content $(\mathrm{r}=-0.65)$ is shown in Figure 1B.

Functionality parameters correlated with several compositional traits. There was a significant correlation between $\mathrm{pH}$ and the 2 rennet coagulation parameters, $\mathrm{RCT}(\mathrm{r}=0.54)$ and CFR $(\mathrm{r}=-0.58)$. Rennet coagulation time was negatively correlated with CFR $(\mathrm{r}=$ $-0.5)$, ionic calcium $(\mathrm{r}=-0.58)$, and serum calcium $(\mathrm{r}=-0.52)$. Ethanol stability was positively correlated with lactose $(\mathrm{r}=0.66)$ and $\mathrm{RCT}(\mathrm{r}=0.61)$.

\section{Variations Between Farms}

Least squares means of individual samples grouped according to farm and sampling period are presented in Table 3. Variations in milk composition and function- 
ality within each farm at each sampling period were observed. Within farms, little variation was found in protein and lactose content, $\mathrm{pH}$, conductivity, total calcium, or ethanol stability, whereas yield, fat content, urea, citrate, serum calcium, ionic calcium, RCT, and CFR varied more. Especially, citrate and urea varied much more between cows on $\mathrm{O} 1$ and $\mathrm{O} 2$ compared with variation between cows on $\mathrm{C} 1$. Ionic calcium showed a large variation between cows from $\mathrm{O} 1$ compared with $\mathrm{O} 2$ and $\mathrm{C} 1$. The effects of farm and feeding period, as well as a potential farm by period interaction for DIM, overall milk composition, and functionality, are also presented in Table 3 . The cows included from the 3 farms did not vary in DIM $(P=0.32)$. However, there was a significant change in DIM due to season, as the same cows were sampled at all sampling times and thus were further in lactation at P2 and P3.

Farm significantly affected all milk compositional traits, except for $\mathrm{pH}$ and $\mathrm{RCT}$. Cows from $\mathrm{O} 2$ had significantly lower milk yield than did cows from $\mathrm{O} 1$ and $\mathrm{C} 1$, respectively. The organic farms had significantly lower protein and lactose contents compared with C1. Farm O2 had significantly higher fat content than did $\mathrm{O} 1$ or $\mathrm{C} 1$. Urea levels were significantly different between all farms, with $\mathrm{O} 2$ having the lowest and $\mathrm{O} 1$ the highest levels. Citrate levels were significantly lower for $\mathrm{O} 1$ than for $\mathrm{C} 1$. Conductivity, which is a measure of the concentration of anions and cations present in milk, was significantly higher for $\mathrm{O} 1$ than for $\mathrm{O} 2$ or $\mathrm{C} 1$. Farm C1 showed a CFR significantly higher than those of the organic farms. Ethanol stability was significantly higher for $\mathrm{C} 1$ than for the organic farms.

Total calcium content and the distribution of micellar and soluble calcium compositions in the milk samples are shown in Table 4. The results are shown as least squares means of the individual milk samples, grouped according to farm and feeding period, and tested for significant differences between farm, feeding period, and the interaction of farm and feeding period. Except for the amount of complexed serum calcium, total calcium content and distributions were significantly different between farms. Levels of total and micellar calcium contents were significantly lower for O1 than for O2 or C1. Farm O2 had significantly higher levels of serum calcium and ionic calcium than did $\mathrm{O} 1$ or $\mathrm{C} 1$, with O1 having significantly higher content of ionic calcium than $\mathrm{C} 1$.

A significant effect of farm was observed for the ratio between ionic calcium and total calcium, whereas the ratios between micellar, complexed serum, and serum calcium to total calcium, respectively, were not significantly different among the farms. The ratio between ionic calcium and citrate along with the ratio between serum calcium and citrate were calculated to examine

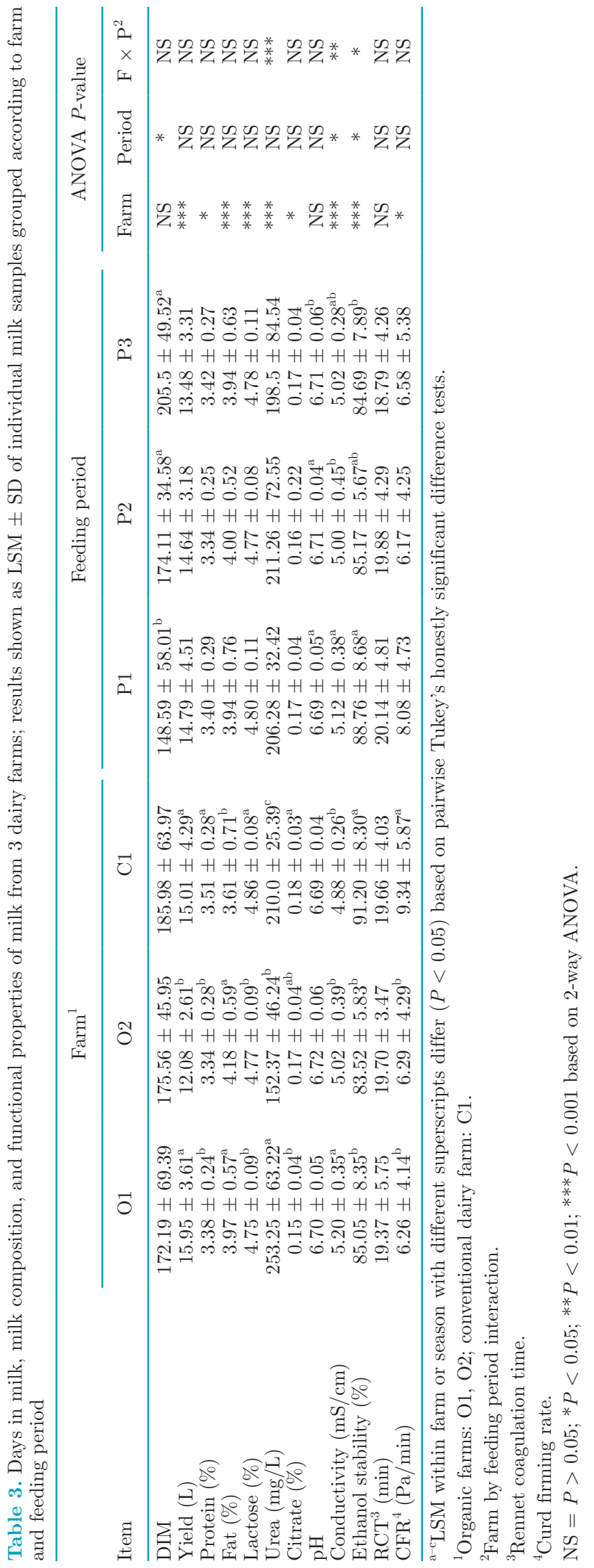

Journal of Dairy Science Vol. 102 No. 8, 2019 


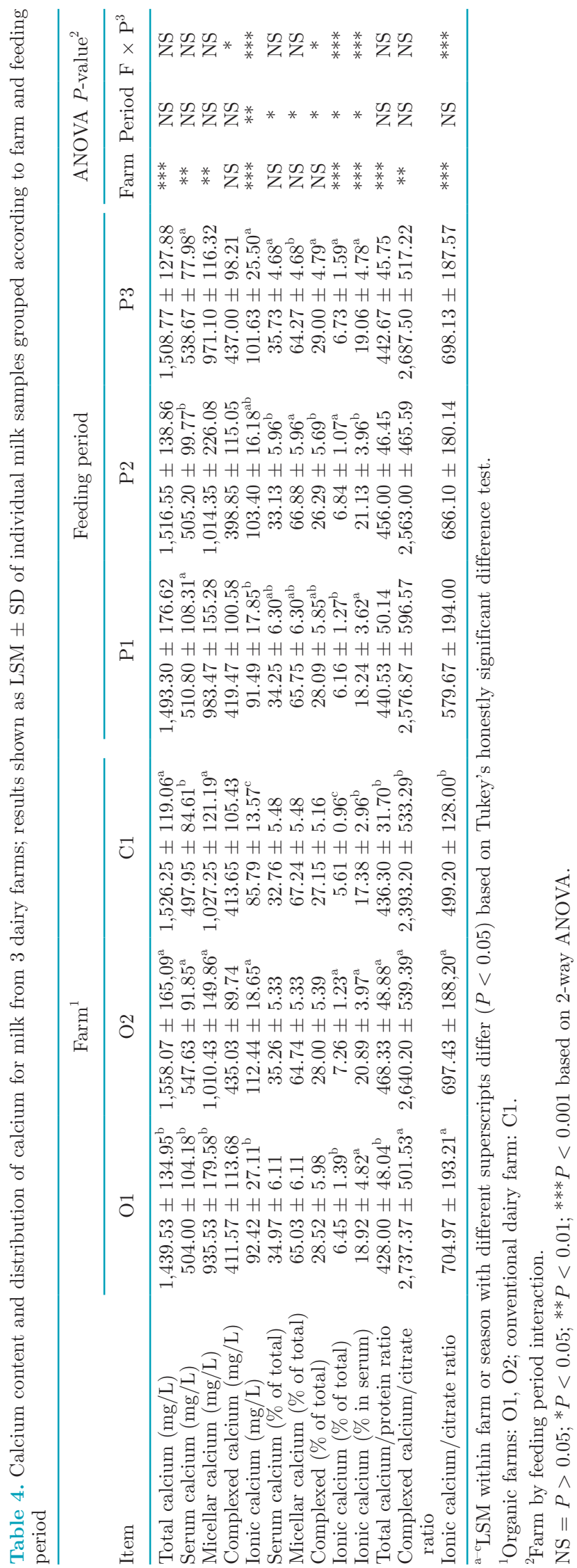

the relationship between these parameters. The ratios were significantly affected by farm, with $\mathrm{O} 2$ having significantly lower complexed calcium in serum but significantly higher ionic calcium in serum than did $\mathrm{O} 1$ or $\mathrm{C} 1$. The ratio between protein and total calcium was significantly higher for $\mathrm{O} 2$, but $\mathrm{O} 1$ and $\mathrm{C} 1$ did not differ from each other. Finally, C1 had significantly lower ratios of complexed calcium to citrate and ionic calcium to citrate than did the organic farms.

\section{Effect of Feeding Period}

Feeding period affected only a few of the analyzed parameters, as shown in Table 3. Lower ethanol stability and conductivity were measured at P2 and P3 compared with P1. For the calcium distribution, only ionic calcium levels varied significantly between feeding periods (Table 4), with the highest levels at P3.

Although ionic calcium was significantly lower at P2 compared with $\mathrm{P} 1$ and P3, only a tendency was observed across all 3 sampling times $(P=0.07)$. When analyzing different calcium distributions, the distribution of serum, micellar, complexed serum, and ionic calcium as fractions of total calcium showed significant variation, with higher levels at P2 than P1 and P3, for all distributions except ionic calcium (Table 4). For ionic calcium, significantly higher levels were observed during pasture feeding (P2 and P3) compared with $\mathrm{P} 1$. Complexed serum and ionic calcium as fractions of serum calcium were significantly affected by feeding period, with lower levels of complexed calcium at P2 compared with levels at P1 or P3 and, likewise, higher levels of ionic calcium. The ratios of total calcium to protein, and of complexed serum calcium to citrate, were similar at all sampling times.

Significant interactions between farm and feeding period were observed for urea content, conductivity, and ethanol stability (Table 3). Furthermore, significant interactions between farm and period for complexed serum and ionic calcium contents were observed (Table $4)$. In Figure 2 the highly significant interactions ( $P$ $<0.001$ ) between farm and period are presented for urea and ionic calcium. Urea content from each farm at the different sampling times is shown in Figure 2A. Milk from $\mathrm{O} 2$ showed significantly lower urea from $\mathrm{P} 1$ to P2 and P3, although urea levels in milk from O1 increased from P1 to P3, and no change was observed for urea levels in milk from $\mathrm{C} 1$ from P1 to P3 (Figure $2 \mathrm{~A})$. Likewise, the ionic calcium levels were different for the 3 farms, as shown in Figure 2B. Ionic calcium significantly increased from $\mathrm{P} 1$ to $\mathrm{P} 3$ for $\mathrm{O} 2$ and $\mathrm{C} 1$, while a decrease was observed from $\mathrm{P} 1$ and $\mathrm{P} 2$ to $\mathrm{P} 3$ for O1 milk (Figure 2B). 


\section{DISCUSSION}

Actual milk yield, overall milk composition, coagulation properties, and calcium content all accord with values and content levels previously reported for Danish Holstein cows (Jensen et al., 2012b; Poulsen et al., 2013). To our knowledge, this is the first time ethanol stability has been reported for milk from Danish Holsteins. Our results clearly illustrate that both management practices (organic versus conventional) and feeding strategies have strong effects on milk composition. The effects of changes in feed composition on the selected milk compositional traits were minor in this study. Specifically, an increased understanding of the interactions between natural variability in levels of citrate and different calcium compositions was of interest, as few studies, to our knowledge, have addressed this. Also, the relation between urea and other minor milk compositional traits has not been addressed previously.

\section{Correlations Between Milk Variables}

Citrate acts as a strong chelating agent for calcium in milk, and a positive correlation between citrate and serum calcium was expected (Gaucheron, 2005). Manipulating citrate levels in milk, by addition of citrate after the milk has been synthesized, has been reported to decrease levels of ionic calcium (Ozcan-Yilsay et al., 2007). This potential relationship was not observed in the raw milk from this study, as no correlation between ionic calcium and citrate was found $(P=0.27)$. However, the positive association between complexed serum calcium and total citrate observed here is in agreement with White and Davies (1958), who observed a positive correlation between complexed serum calcium and soluble citrate in individual cows' milk in mid lactation. Similar results were observed by Bijl et al. (2013), who reported a correlation between serum citrate and serum calcium for both individual cows' milk and bulk tank milk samples.

Calcium is expected to be in equilibrium in milk between micellar, serum, and ionic phases. Addition of citrate could therefore be expected to change this equilibrium by formation of complexes with calcium in serum, causing a migration of calcium from the casein micelle. This could negatively affect the coagulation properties, as both ionic and micellar calcium are important for these (Koutina et al., 2015; Maciel et al., 2015). Tsioulpas et al. (2007b) suggested that more ionic calcium present naturally in the milk reduces the net negative charge of the casein micelles and thereby promotes instability. Sundekilde et al. (2011) observed that higher natural concentration of citric acid could be
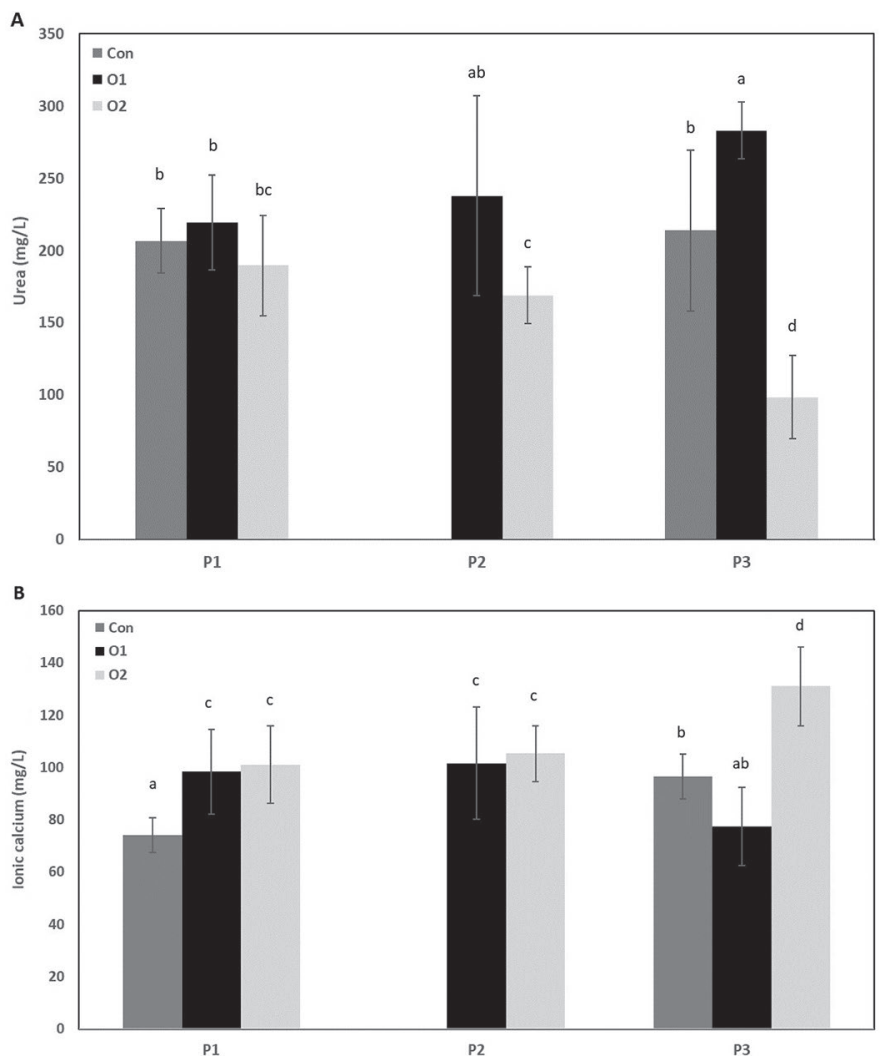

Figure 2. Variations in $(\mathrm{A})$ urea $(\mathrm{mg} / \mathrm{L})$ and $(\mathrm{B})$ ionic calcium $(\mathrm{mg} / \mathrm{L})$ for each farm at each sampling time. P1, P2, P3 = feeding period. $\mathrm{C} 1=$ conventional dairy farm; $\mathrm{O} 1, \mathrm{O} 2=$ organic farms. Results are presented as means; error bars indicate SD. Letters (a-d) indicate significant differences $(P<0.05)$ based on 2 -way ANOVA test.

associated with poor coagulation. However, our study found that natural variation in ionic calcium and RCT were negatively correlated, which is in line with results by Nian et al. (2012) and Gustavsson et al. (2014). Likewise, addition of calcium to milk before rennet coagulation increases total serum and ionic calcium and decreases RCT by weakening the repulsion between casein micelles (Lucey and Fox, 1993).

The positive association between total and micellar calcium and milk coagulation properties reported in previous studies (Jensen et al., 2012b) was not observed here, despite a positive correlation between total protein content and the content of micellar calcium. Ethanol stability is decreased by increasing the soluble salts in milk, but decreased $\mathrm{pH}$ has also been shown to negatively affect ethanol stability (Horne and Muir, 1990). In this study, ethanol stability and ionic calcium were found to be negatively correlated, in agreement with previous findings of Davies and White (1958), who observed decreased ethanol stability at higher levels of ionic calcium. Likewise, Chavez et al. (2004) observed a tendency toward lower ethanol stability when ionic cal- 
cium increased in raw bulk milk samples $(P<0.1)$. A negative linear relationship between ionic calcium and $\mathrm{pH}$ has been proven in various studies by altering $\mathrm{pH}$ or changing the calcium balance in milk, or both (Tsioulpas et al., 2007b; Koutina et al., 2014). Tsioulpas et al. (2007b) also observed this relationship, with higher $\mathrm{pH}$ leading to lower ionic calcium levels in colostrum milk and in milk from early-lactation cows. Grimley et al. (2009) observed a weak but significant correlation of ionic calcium and $\mathrm{pH}$ in bulk milk samples collected in spring. However, Nian et al. (2012) observed a weak correlation for individual milk samples between ionic calcium and $\mathrm{pH}$, and suggested that they are independent variables in raw milk, which also seems to be the case in our study, as we observed no significant correlation between ionic calcium and $\mathrm{pH}(P=0.39)$. This corresponds well with observations by Holt (2011), who states that the equilibrium state between ionic calcium and hydrogen phosphate occurring naturally in milk is independent of $\mathrm{pH}$.

Ionic calcium and urea exhibited a negative correlation in raw milk, as shown in Figure 1b. Geishauser and Oekentorp (1997) observed a significant correlation between ionized calcium and urea in the blood of dairy cows. Generally, natural variation in milk urea has been linked to heat stability, with higher urea content leading to more heat-stable milk at natural $\mathrm{pH}$ (Lewis and Deeth, 2008). The stabilizing effect of urea has been linked to urea's ability to buffer against heat-induced acidification, along with the binding of urea to lysine and cysteine, which hinders Maillard reactions (Metwalli et al., 1996). Chen et al. (2014) did not observe any significant correlation between urea and other components naturally occurring in milk. However, to be able to conclude whether correlation between urea and ionic calcium in milk is causal, more studies exploring this relationship must be performed.

\section{Effect of Management System and Farm}

Increasing shares of grass in organic management is well known to affect particular fatty acid composition and fat-soluble antioxidants (Moorby et al., 2009; Larsen et al., 2014). In our study, C1 represents a conventional farm, where cows are housed indoor all year and only minor changes in feed are realized. In contrast, milk from the 2 organic farms was expected to display larger variation, with a clear effect from grass feeding. However, with high amounts of concentrate fed to cows at both $\mathrm{C} 1$ and $\mathrm{O} 1$, milk from $\mathrm{O} 1$ displayed a composition intermediate between $\mathrm{C} 1$ and $\mathrm{O} 2$ for most traits.

Generally, protein concentration and composition in milk is less sensitive to changes in diet and manage- ment than are fat and, in particular, fatty acid composition. However, type and amount of silage and grains, along with total energy intake, can affect milk protein concentration and composition (Vanhatalo et al., 2008; Moorby et al., 2009; Bilik and Łopuszańska-Rusek, 2010). Poulsen et al. (2015) looked at bulk milk samples from organic and conventional dairies in Denmark and observed lower protein content in the organic milk, as also observed in this study at farm level. This could be related to the generally limited use of concentrate in organic production (Rius et al., 2010) or to increased protein and energy intake with use of TMR feeding systems (Schroeder et al., 2003).

Urea is often used as an indicator for level of protein feeding. When maximum conversion of crude protein to milk is achieved, no effect of additional crude protein supplementation is observed, resulting in higher milk urea levels (Cabrita et al., 2007).

Garnsworthy et al. (2006) observed changes in citrate content according to lactation stage, with the highest citrate concentration in early lactation and no differences between mid- and late lactation. This was independent of feeding and milk yield. This could explain why there were no differences in citrate levels in this study.

Increases in protein and mineral content are associated with improved milk coagulation, decreasing RCT and increasing CFR (Jensen et al., 2012a). It was therefore also expected that $\mathrm{C} 1$ would exhibit improved CFR, due to higher protein content. However, increased levels of both total and ionic calcium, along with a higher calcium-to-protein ratio, did not improve rennet coagulation of $\mathrm{O} 2$ compared with $\mathrm{O} 1$. This is in agreement with Tsioulpas et al. (2007b), who observed no significant change in RCT with milk ionic calcium levels from 1.5 to $2.7 \mathrm{mM}$. Similar results were obtained by Nian et al. (2012), who observed that, on the one hand, increased ionic calcium in milk led to improved rennet coagulation properties, but, on the other hand, it also led to a decrease in heat stability during UHT processing, accompanied by an increase in sedimentation during storage of UHT-treated milk.

\section{Effect of Feeding Period}

The variations caused by changes in feeding in this study were limited, and change did not occur in the same manner for the organic farms when going from indoor to pasture feeding. Generally, lower protein and fat contents have been observed during summer, primarily caused by changes in feeding, including changes to the forage-to-concentrate ratio (Lindmark-Månsson et al., 2003; Heck et al., 2009). However, no changes in protein or fat content were observed in this study. 
O'Callaghan et al. (2016) observed the opposite, with higher protein content in feeding systems containing grass compared with a TMR diet throughout the entire lactation period. Couvreur et al. (2006) observed no significant changes in total fat content but an increase in protein content, when corn silage was replaced by fresh grass in the diet. However, Couvreur and colleagues observed a tendency toward lower fat percentage $(P<$ 0.1 ) for cows on a $100 \%$ grass diet. A similar tendency was observed for $\mathrm{O} 2$, which had $60 \%$ grass in the feeding system during summer pasture in P2 and P3.

When cows are fed pasture, the de novo fatty acid synthesis is found to decrease (Kelly et al., 1998; Elgersma et al., 2004). A linear increase in long-chain fatty acids and a decrease in the synthesis of short- and medium-chain fatty acids has been observed in several studies, when feeding with increasing levels of fresh grass (Baumgard et al., 2000; Lock and Garnsworthy, 2003; Couvreur et al., 2006). Even though none of these studies measured levels of milk citrate directly, a lower de novo synthesis is expected to lead to an increase in milk citrate. We would therefore have expected to observe an increase in citrate for the organic farms when cows there were put on pasture. This was not observed, even when $60 \%$ of the feeding for O2 was fresh grass during P2 and P3. Chen et al. (2014) also did not observe any seasonal effect on citrate level. This could indicate that citrate is less sensitive to change in feeding than expected.

Linzell et al. (1976) suggested that citrate in milk is synthesized within the secretory cells and transported to milk by exocytosis. Furthermore, they found that lactating goat mammary gland epithelium was impermeable to citrate in both directions. This could indicate that milk citrate is not easily manipulated by feeding. In many studies, citrate content in milk has been confounded by lactation stage and season. Garnsworthy et al. (2006) observed higher levels of citrate in early lactation, independent of feeding. As all cows in our study were in mid lactation, the results presented here seem to be in line with Garnsworthy et al. (2006).

Cows with access to high-quality grass are expected to have higher levels of urea, due to consuming excess protein, which corresponds well to our findings for O1. The decrease for $\mathrm{O} 2$ could be related to less feeding of concentrate and silage during the pasture-feeding period. However, as the protein content in the milk did not decrease, cows' protein consumption remained sufficient. The amount of energy intake from pasture at the 2 organic farms was estimated based on a prediction of cows' daily consumption. It could therefore be speculated that cows at $\mathrm{O} 2$ did not reach this level, and cows at $\mathrm{O} 1$ consumed an excess of energy. This could indicate that $\mathrm{O} 1$ has excess protein in the diet compared with $\mathrm{O} 2$, especially, and, to a lesser degree, compared with $\mathrm{C} 1$, and thereby also higher levels of urea.

Total milk calcium has previously been shown to be subject to seasonal variation, due to linkage to changes in protein content (Heck et al., 2009). However, in our study no seasonal changes in milk total calcium content were observed, as evident in Table 4. Grandison et al. (1984) observed an increase in coagulum strength when changing to spring grazing, which was related to increases in casein and mineral content and a tendency toward longer RCT as summer progressed.

No changes in protein or total calcium were observed in the present study, and this corresponds with no changes in rennet coagulation properties. Other studies have reported conflicting results for ionic calcium levels by season. Chen et al. (2014) observed significant differences in ionic calcium, as influenced by season, but Grimley et al. (2009) observed only a small reduction in ionic calcium levels in spring. Along with the results of our study, this could indicate that ionic calcium can be affected not only by pasture feeding but also by management and supplementary feeding, along with type of grass.

\section{CONCLUSIONS}

In summary, our study demonstrated a positive correlation between complexed serum calcium and citrate in fresh milk. Furthermore, we observed a negative correlation between urea and ionic calcium. However, the latter correlation needs further investigation to conclude whether this is a causal relationship. Moreover, milk from different farms does not vary only according to organic versus conventional farming systems; feeding also plays a major role in milk composition and functionality. Only a few traits changed significantly in milk from the organic farms when cows went on pasture. None of these changes were found to have a negative effect on milk functionality and would thereby not cause processing problems. No change in citrate levels was observed, which suggests that other mechanisms than feeding have an effect on citrate levels in milk. Furthermore, as no correlations were found between natural variation in citrate and functional properties, citrate level does not seem to be a suitable candidate for prediction of functional qualities of raw milk.

\section{ACKNOWLEDGMENTS}

We thank the farmers on each studied farm for their support and for providing milk samples. We also thank Gitte H. Kristiansen and M. M. Alkhalef for their assistance in analyzing milk samples. This work was 
financially supported by Arla Foods amba (Viby J, Denmark) and Aarhus University (Aarhus, Denmark).

\section{REFERENCES}

Baumgard, L. H., B. A. Corl, D. A. Dwyer, A. Saebø, and D. E. Bauman. 2000. Identification of the conjugated linoleic acid isomer that inhibits milk fat synthesis. Am. J. Physiol. Regul. Integr. Comp. Physiol. 278:R179-R184.

Bijl, E., H. J. F. van Valenberg, T. Huppertz, and A. C. M. van Hooijdonk. 2013. Protein, casein, and micellar salts in milk: Current content and historical perspectives. J. Dairy Sci. 96:5455-5464.

Bilik, K., and M. Łopuszańska-Rusek. 2010. Effect of organic and conventional feeding of Red-and-White cows on productivity and milk composition. Ann. Anim. Sci. 10:441-458.

Boumpa, T., A. Tsioulpas, A. S. Grandison, and M. J. Lewis. 2008 Effects of phosphates and citrates on sediment formation in UHT goats' milk. J. Dairy Res. 75:160-166.

Cabrita, A. R. J., R. J. B. Bessa, S. P. Alves, R. J. Dewhurst, and A. J. M. Fonseca. 2007. Effects of dietary protein and starch on intake, milk production, and milk fatty acid profiles of dairy cows fed corn silage-based diets. J. Dairy Sci. 90:1429-1439.

Chavez, M. S., L. M. Negri, M. Taverna, and A. Cuatrin. 2004. Bovine milk composition parameters affecting ethanol stability. J. Dairy Res. 71:201-206.

Chen, B., M. J. Lewis, and A. S. Grandison. 2014. Effect of seasonal variation on the composition and properties of raw milk destined for processing in the UK. Food Chem. 158:216-223.

Couvreur, S., C. Hurtaud, C. Lopez, L. Delaby, and J. L. Peyraud 2006. The linear relationship between the proportion of fresh grass in the cow diet, milk fatty acid composition, and butter properties. J. Dairy Sci. 89:1956-1969.

Davies, D. T., and J. C. D. White. 1958. The relation between the chemical composition of milk and the stability of the caseinate complex: II. Coagulation by ethanol. J. Dairy Res. 25:256-266.

Elgersma, A., G. Ellen, H. van der Horst, H. Boer, P. R. Dekker, and S. Tamminga. 2004. Quick changes in milk fat composition from cows after transition from fresh grass to a silage diet. Anim. Feed Sci. Technol. 117:13-27.

European Council. 2007. Council Regulation (EC) No 834/2007 of 28 June 2007 on organic production and labelling of organic products and repealing Regulation (EEC) No 2092/91. L. o. F. Ministeriet for Fødevarer, ed. https://eur-lex.europa.eu/legal-content/EN/ TXT/?uri=celex\%3A32007R0834.

Faulkner, A., E. Y. Brechany, R. M. Mabon, and H. T. Pollock. 1986. Seasonal changes in the fat composition and concentration of citrate and related metabolites in cows' milk. J. Dairy Res. 52:223227.

Faulkner, A., and M. Peaker. 1982. Reviews of the progress of dairy science: Secretion of citrate into milk. J. Dairy Res. 49:159-169.

Frederiksen, P. D., M. Hammershøj, M. Bakman, P. N. Andersen, J. B. Andersen, K. B. Quist, and L. B. Larsen. 2011. Variations in coagulation properties of cheese milk from three Danish dairy breeds as determined by a new free oscillation rheometry-based method. Dairy Sci. Technol. 91:309-321.

Garnsworthy, P. C., L. L. Masson, A. L. Lock, and T. T. Mottram. 2006. Variation of milk citrate with stage of lactation and de novo fatty acid synthesis in dairy cows. J. Dairy Sci. 89:1604-1612.

Gaucheron, F. 2005. The minerals of milk. Reprod. Nutr. Dev. 45:473483.

Geishauser, T., and N. Oekentorp. 1997. The association between ionized calcium in blood and selected parameters in dairy cows with left displaced abomasum. Zentralbl. Veterinarmed. A 44:493-500.

Grandison, A., G. D. Ford, A. Jane Owen, and D. Millard. 1984. Chemical composition and coagulating properties of renneted Friesian milk during the transition from winter rations to spring grazing. J. Dairy Res. 51:69-78.

Grimley, H., A. Grandison, and M. Lewis. 2009. Changes in milk composition and processing properties during the spring flush period. Dairy Sci. Technol. 89:405-416.
Gustavsson, F., A. J. Buitenhuis, M. Glantz, H. Stålhammar, H. Lindmark-Månsson, N. A. Poulsen, L. B. Larsen, A. Andrén, and M. Paulsson. 2014. Impact of genetic variants of milk proteins on chymosin-induced gelation properties of milk from individual cows of Swedish Red dairy cattle. Int. Dairy J. 39:102-107.

Heck, J. M. L., H. J. F. van Valenberg, J. Dijkstra, and A. C. M. van Hooijdonk. 2009. Seasonal variation in the Dutch bovine raw milk composition. J. Dairy Sci. 92:4745-4755.

Holt, C. 1982. Inorganic constituents of milk III. The colloidal calcium phosphate of cow's milk. J. Dairy Res. 49:29-38.

Holt, C. 2011. Milk salts and their interaction with caseins. Pages 2007-2015 in Encyclopedia of Dairy Sciences. Vol. 3. H. Roginski, J. Fuquay, and P. F. Fox, ed. Academic Press, London, UK.

Holt, C., and R. Jenness. 1984. Interrelationships of constituents and partition of salts in milk samples from eight species. Comp. Biochem. Physiol. A Comp. Physiol. 77:275-282.

Horne, D. S., and D. D. Muir. 1990. Alcohol and heat stability of milk protein. J. Dairy Sci. 73:3613-3626.

Jensen, H. B., J. W. Holland, N. A. Poulsen, and L. B. Larsen. 2012a. Milk protein genetic variants and isoforms identified in bovine milk representing extremes in coagulation properties. J. Dairy Sci. 95:2891-2903.

Jensen, H. B., N. A. Poulsen, K. K. Andersen, M. Hammershøj, H. D. Poulsen, and L. B. Larsen. 2012b. Distinct composition of bovine milk from Jersey and Holstein-Friesian cows with good, poor, or noncoagulation properties as reflected in protein genetic variants and isoforms. J. Dairy Sci. 95:6905-6917.

Kelly, M. L., E. S. Kolver, D. E. Bauman, M. E. Van Amburgh, and L. D. Muller. 1998. Effect of intake of pasture on concentrations of conjugated linoleic acid in milk of lactating cows. J. Dairy Sci. $81: 1630-1636$

Koutina, G., J. C. Knudsen, U. Andersen, and L. H. Skibsted. 2014. Temperature effect on calcium and phosphorus equilibria in relation to gel formation during acidification of skim milk. Int. Dairy J. 36:65-73.

Koutina, G., J. C. Knudsen, U. Andersen, and L. H. Skibsted. 2015. Influence of colloidal calcium phosphate level on the microstructure and rheological properties of rennet-induced skim milk gels. Lebensm. Wiss. Technol. 63:654-659.

Larsen, M. K., K. K. Andersen, N. Kaufmann, and L. Wiking. 2014 Seasonal variation in the composition and melting behavior of milk fat. J. Dairy Sci. 97:4703-4712.

Lewis, M., A. Grandison, M.-J. Lin, and A. Tsioulpas. 2011. Ionic calcium and $\mathrm{pH}$ as predictors of stability of milk to UHT processing. Milchwissenschaft 66:197-200.

Lewis, M. J. 2011. The measurement and significance of ionic calcium in milk-A review. Int. J. Dairy Technol. 64:1-13.

Lewis, M. J., and H. C. Deeth. 2008. Heat treatment of milk. Pages 168-204 in Milk Processing and Quality Management. A. Y. Tamime, ed. Blackwell Publishing Ltd., Oxford, UK.

Lin, M. J., M. J. Lewis, and A. S. Grandison. 2006. Measurement of ionic calcium in milk. Int. J. Dairy Technol. 59:192-199.

Lindmark-Månsson, H., R. Fondén, and H.-E. Pettersson. 2003. Composition of Swedish dairy milk. Int. Dairy J. 13:409-425.

Linzell, J. L., T. B. Mepham, and M. Peaker. 1976. The secretion of citrate into milk. J. Physiol. 260:739-750.

Lock, A. L., and P. C. Garnsworthy. 2003. Seasonal variation in milk conjugated linoleic acid and $\Delta 9$ desaturase activity in dairy cows. Livest. Prod. Sci. 79:47-59.

Lucey, J. A., and P. F. Fox. 1993. Importance of calcium and phosphate in cheese manufacture: A review. J. Dairy Sci. 76:1714-1724.

Maciel, G. d., M. Hammersh øj, P. Frederiksen, J. Sørensen, M. Bakman, N. Poulsen, and L. Larsen. 2015. Dairy processing and cold storage affect the milk coagulation properties in relation to cheese production. Dairy Sci. Technol. 95:101-114.

Metwalli, A. A. M., N. H. Metwalli, and M. A. J. van Boekel. 1996. Effect of urea on heat-induced changes in milk. Neth. Milk Dairy J. 50:459-576.

Moorby, J. M., M. R. F. Lee, D. R. Davies, E. J. Kim, G. R. Nute, N. M. Ellis, and N. D. Scollan. 2009. Assessment of dietary ratios of 
red clover and grass silages on milk production and milk quality in dairy cows. J. Dairy Sci. 92:1148-1160.

Nian, Y., B. Y. Chen, P. Aikman, A. Grandison, and M. Lewis. 2012. Naturally occurring variations in milk $\mathrm{pH}$ and ionic calcium and their effects on some properties and processing characteristics of milk. Int. J. Dairy Technol. 65:490-497.

O'Callaghan, T. F., D. Hennessy, S. McAuliffe, K. N. Kilcawley, M. O'Donovan, P. Dillon, R. P. Ross, and C. Stanton. 2016. Effect of pasture versus indoor feeding systems on raw milk composition and quality over an entire lactation. J. Dairy Sci. 99:9424-9440.

Ozcan-Yilsay, T., W. J. Lee, D. Horne, and J. A. Lucey. 2007. Effect of trisodium citrate on rheological and physical properties and microstructure of yogurt. J. Dairy Sci. 90:1644-1652.

Poulsen, N. A., H. P. Bertelsen, H. B. Jensen, F. Gustavsson, M. Glantz, H. Lindmark Månsson, A. Andrén, M. Paulsson, C. Bendixen, A. J. Buitenhuis, and L. B. Larsen. 2013. The occurrence of noncoagulating milk and the association of bovine milk coagulation properties with genetic variants of the caseins in 3 Scandinavian dairy breeds. J. Dairy Sci. 96:4830-4842.

Poulsen, N. A., A. J. Buitenhuis, and L. B. Larsen. 2015. Phenotypic and genetic associations of milk traits with milk coagulation properties. J. Dairy Sci. 98:2079-2087.

Poulsen, N. A., M. Glantz, A. K. Rosengaard, M. Paulsson, and L. B. Larsen. 2017a. Comparison of milk protein composition and rennet coagulation properties in native Swedish dairy cow breeds and high-yielding Swedish Red cows. J. Dairy Sci. 100:8722-8734.

Poulsen, N. A., V. R. Gregersen, G. M. Maciel, L. B. Madsen, B. Buitenhuis, M. S. Hansen, C. Bendixen, and L. B. Larsen. 2017b. Novel genetic variation associated to CSN3 strongly affects rennetinduced milk coagulation. Int. Dairy J. 71:122-130.

Rius, A. G., J. A. D. R. N. Appuhamy, J. Cyriac, D. Kirovski, O. Becvar, J. Escobar, M. L. McGilliard, B. J. Bequette, R. M. Akers, and M. D. Hanigan. 2010. Regulation of protein synthesis in mam- mary glands of lactating dairy cows by starch and amino acids. J. Dairy Sci. 93:3114-3127.

Schroeder, G. F., J. E. Delahoy, I. Vidaurreta, F. Bargo, G. A. Gagliostro, and L. D. Muller. 2003. Milk fatty acid composition of cows fed a total mixed ration or pasture plus concentrates replacing corn with fat. J. Dairy Sci. 86:3237-3248.

Sundekilde, U. K., P. D. Frederiksen, M. R. Clausen, L. B. Larsen, and H. C. Bertram. 2011. Relationship between the metabolite profile and technological properties of bovine milk from two dairy breeds elucidated by NMR-based metabolomics. J. Agric. Food Chem. 59:7360-7367.

Sundekilde, U. K., F. Gustavsson, N. A. Poulsen, M. Glantz, M. Paulsson, L. B. Larsen, and H. C. Bertram. 2014. Association between the bovine milk metabolome and rennet-induced coagulation properties of milk. J. Dairy Sci. 97:6076-6084.

Tsioulpas, A., A. S. Grandison, and M. J. Lewis. 2007a. Changes in physical properties of bovine milk from the colostrum period to early lactation. J. Dairy Sci. 90:5012-5017.

Tsioulpas, A., M. J. Lewis, and A. S. Grandison. 2007b. Effect of minerals on casein micelle stability of cows' milk. J. Dairy Res. 74:167-173.

Udabage, P., I. R. McKinnon, and M. A. Augustin. 2001. Effects of mineral salts and calcium chelating agents on the gelation of renneted skim milk. J. Dairy Sci. 84:1569-1575.

Vanhatalo, A., T. Gäddnäs, and T. Heikkilä. 2008. Microbial protein synthesis, digestion and lactation responses of cows to grass or grass-red clover silage diet supplemented with barley or oats. Agric. Food Sci. 15:252-267.

White, J. C. D., and D. T. Davies. 1958. The relation between the chemical composition of milk and the stability of the caseinate complex. I: General introduction, description of samples, methods and chemical composition of samples. J. Dairy Res. 25:255-263. 